Copyright (C) 2021 University of Bucharest Printed in Romania. All rights reserved

ISSN print: $1224-5984$

ISSN online: $2248-3942$
Rom Biotechnol Lett. 2021; 26(1): 2262-2268 doi: $10.25083 / \mathrm{rbl} / 26.1 / 2262.2268$

Received for publication, September, 6, 2020

Accepted, October, 10, 2020

Original paper

\title{
Characterization of Checo/f95-927 pea (Pisum sativum L.) population for winter frost tolerance using molecular markers
}

\author{
ANCUȚA CRÎNGAȘU (BĂRBIERU) ${ }^{1,2 \#, ~ M A T I L D A ~ C I U C A ̆ ~}{ }^{2 \#, ~ C R I S T I N A ~ D A N I E L ~}{ }^{2}$, \\ CĂLINA-PETRUȚA CORNEA ${ }^{1}$, GHEORGHE ITTU ${ }^{2}$ and ELENA-LAURA CONȚESCU ${ }^{2 *}$ \\ ${ }^{1}$ University of Agronomic Sciences and Veterinary Medicine in Bucharest, Faculty of \\ Biotechnologies, Bucharest, Romania \\ ${ }^{2}$ National Agricultural Research and Development Institute Fundulea, Romania \\ \#ANCUȚA CRÎNGAȘU (BĂRBIERU) and MATILDA CIUCĂ contributed equally to this paper
}

\begin{abstract}
Winter pea has several advantages on spring pea: higher yield, more rapid spring growth that helps this crop to compete weeds, wider growing area, etc.

The aim of this paper was to evaluate the association of some molecular markers with frost tolerance of pea. Forty-one pea recombinant inbred lines (RILs), from F5 generation, obtained by crossing the winter cultivar Checo with the spring line F95-927 were examined during this work both by in vitro (molecular markers analysis) and in field experiments.

The results obtained showed a significant correlation between frost tolerance and molecular markers EST1109 and AD59. Also, it has been found that the molecular marker $A D 159$ is associated with earliness character.

These associated markers could play an essential role in marker-assisted breeding for winter-hardy pea cultivars.
\end{abstract}

Keywords Winter pea, frost tolerance, molecular markers.

To cite this article: CRÎNGAȘU A., CIUCĂ M., CRISTINA D., CORNEA C.P., ITTU G., CONȚESCU E.L. Characterization of Checo/F95-927 pea (Pisum sativum L.) population for winter frost tolerance using molecular markers. Rom Biotechnol Lett. 2021; 26(1): 2262-2268. DOI: $10.25083 / \mathrm{rbl} / 26.1 / 2262.2268$

*Corresponding author: ELENA-LAURA CONȚESCU, Doctor, National Agricultural Research and Development Institute Fundulea, 915200 Fundulea, 1 Nicolae Titulescu Street, Călăraşi County, Romania, Phone: (40) 2131508 05, (40) 722386 223, (40) 0213154040

E-mail: contescu_elena_laura@yahoo.com 


\section{Introduction}

Pea (Pisum sativum L., $2 \mathrm{n}=14$ ) is an economically important grain legume crop cultivated on over 2.7 millions ha in Europe (FAOSTAT, 2018).

Growing peas provide multiple environmental benefits to European agricultural landscapes, increases resource efficiency, and helps balance European vegetable protein deficit. Field pea has agricultural benefits such as improved soil nitrogen, better weed management and reduced disease for other crops with which it is grown in rotation (SIN and PARTAL, 2010). Accordind to national statistics, field pea was cultivated on 105.002 ha in 2019 , with a total production of 223.005 tones and a medium production of $2125 \mathrm{~kg} / \mathrm{ha}$ (https://insse.ro/).

All winter crops are limited by low temperatures and other stresses associated with unfavorable climatic conditions. To cope with these harsh conditions, plants must develop adaptative responses to weather changes, field pea makes no exeception to this rules.

Field pea has three phenological groups: spring, Mediterranean and winter pea (STODDARD, 2006). Across all three groups, inadequate tolerance to low temperature stresses is a significant problem. In many countries where field pea is sown in winter or spring, frost damage occurs at the seedling stage (BADARUDDIN and MEYER, 2001). Severe frost damage can completely kills pea seedlings, requiring re-sowing of the crop (MEYER and BADARUDDIN, 2001).

Important progresses for understanding cold acclimation, frost escape and frost tolerance of pea were made by the extended use of molecular markers. They are useful complement to morphological and phenological characters because they are plentiful, independent of tissue or environmental effects, and allow indirect selection of interested traits at an early development stage.

Lejeune-Henaut (2008) and Weller (2012) found that the flowering locus $\mathrm{Hr}$ co-localize with a major gene (on LG3) which controls sensitivity to photoperiod. Presence of $\mathrm{Hr}$ allele in a pea cultivar/line could be useful for cold season freezing defense, knowing that lines with $\mathrm{Hr}$ phenotype delays floral initiation time until the day length reaches $13 \mathrm{~h} 30 \mathrm{~min}$. Other mechanisms than can confer resistance to winter frost damages were suggested, and their existence was validated by identifying new QTLs (LEJEUNE-HENAUT, 2008).

Several studies on the genetic determinism of winter frost tolerance have established the importance of some cold acclimation key characters like activity of $\mathrm{RuBisCO}$, concentrations of sugars and electrolyte leakage, and new QTL on LG5 (near marker AA475) and LG6 (near markers $A D 159, A D 141$ and $A D 59$ ) linked to cold acclimation were detected (DUMOT, 2009; KLEIN, 2014). These results are suggesting that not only plant architecture or flowering ideotype can influence plant resistance but also other protective mechanisms like content in raffinose, large number of branches, high chlorophyll content after winter, are involved.

Significant association of the functional marker EST 1109 on LGVI with frost tolerance was demonstrated in recent studies, suggesting that it is co-localizing with a gene involved in the metabolism of glycoproteins in response to chilling stress. These data provide a novel mechanism of frost tolerance in pea, which represents helpful references on plant response to the chilling stress (LIU, 2017).

The objectives of this study were as follows: to screen for winter-hardy pea recombinant inbred lines obtained from Checo and F95-927 cross and to assess the pattern of genetic variation of pea recombinant lines for frost tolerance using molecular markers.

\section{Material and Methods}

A total of 41 peas recombinant inbred lines (RILs) derived from the cross between the winter tolerant cultivar Checo (Austria) and susceptible spring line F95-927, were provided by NARDI Fundulea (Breeding protein and fodder plants laboratory).

\section{Frost tolerance test}

The response to frost was studied in seedling stage under winter, natural conditions, without being covered with snow layer. Ten seeds (RIL's and parental forms) were sown on 1 November 2016, in plastic trays (40 x40 $\mathrm{cm}$ ) with a nutrient substrate of $15 \mathrm{~cm}$, each tray including 16 rows (Fig. 1-left). The plants emerged on 7 November and on 14 November the trays with seedlings (about $5 \mathrm{~cm}$ ) were moved in the vegetation house for natural hardening, taking care to remove any snow, till 10 January 2017. For November the lowest temperature was $-3.2^{\circ} \mathrm{C}$ and the warmest was $+15.4^{\circ} \mathrm{C}$. In December the lowest temperature was $-8.8^{\circ} \mathrm{C}$ and the warmest was $+12.5^{\circ} \mathrm{C}$ and in January, till 10 January, the minimum was $-16.3^{\circ} \mathrm{C}$ and the maximum $+5.7^{\circ} \mathrm{C}$. After the frost period, the trays were moved to a heated space $\left(17-19^{\circ} \mathrm{C}\right)$. Frost symptoms were recorded for each seedling using visual scores by appraisal of the starting stage in vegetation of plants (appearance of basal shoots) and the leaves necrosis and seedling survival (Fig. 1-right). The scale for the assessment of winter hardiness ranged between 1 and 9 (1-very resilient, 9 - all dead plants). Also, all RILs and parental forms were cultivated in the field but the plants were covered with snow layer and the frost tolerance evaluation wasn't done.

To appreciate lines earliness we accounted, for each line, the number of days from the first day of January to the end of flowering time in the field of NARDI Fundulea. 

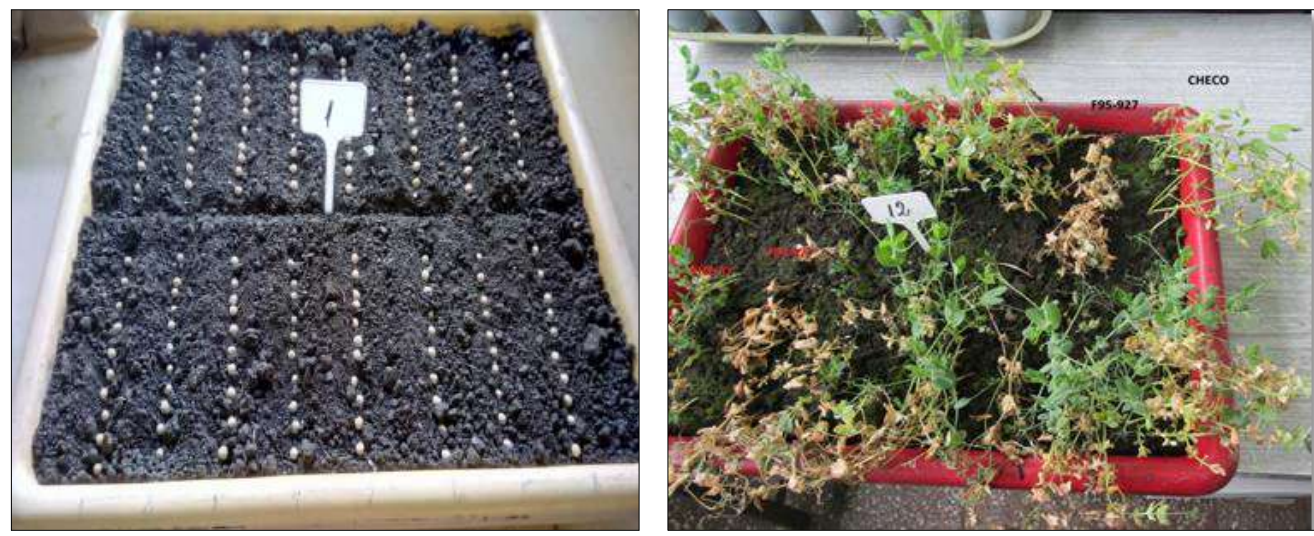

Figure 1. F95-927/Checo RILs after sowing (left) and before scoring for resistance to low temperatures (right).

\section{DNA extraction}

Genomic DNA was isolated from dry pea seeds using the SDS 1 method (CONȚESCU, 2018). After extraction, DNA quality was confirmed by agarose gel electrophoresis and spectrophotometric measurements.

\section{PCR parameters}

PCR amplifications for markers EST1109, AD59 and AA175 were performed with MyTaq ${ }^{\mathrm{TM}}$ Red DNA kit as follows: $30 \mathrm{ng}$ genomic DNA, $4 \mu \mathrm{l}$ Buffer $5 \mathrm{X}, 0.5 \mu \mathrm{M}$ $(1 \mu \mathrm{l})$ of each primer and $0.4 \mathrm{U}$ MyTaq ${ }^{\mathrm{TM}}$ Red DNA Polymerase, reaction volume was $20 \mu$ l. For marker AD159 PCR amplification was performed in $20 \mu 1$ reaction volume containing: $30 \mathrm{ng}$ genomic DNA, $10 \mu \mathrm{l}$ KAPA2G Fast Multiplex $(2 \mathrm{X})$ and $0.5 \mu \mathrm{M}(1 \mu \mathrm{l})$ of each primer.

Statistical analyses were performed in Microsoft Excel (Anova, t-test), heterozygous forms were excluded.

\section{Results and Discussions}

In this study, the test for frost tolerance showed that resilient parent Checo avoided low winter temperatures, being noted with 2 . Spring line F95-927 was susceptible to low temperature and noted with 9 (all the plants died). Regarding the RILs behavior to low temperatures, their value ranged from 1 to 6 .

Molecular results with marker $A A 175$ revealed the presence of $h r$ allele in the resilient parent Checo and also in the susceptible one F95-927. This result suggest that for winter tolerant lines other mechanisms than delayed floral initiation time induced by the presence of $\mathrm{Hr}$ allele are involved.

Other molecular marker used in this study was the functional marker EST1109 (LIU, 2017). This marker showed polymorphism between parents, for Checo was observed a $240 \mathrm{bp}$ product while for the F95-927 line a $245 \mathrm{bp}$ one. Separation of PCR products was carried on $8 \%$ non-denaturing polyacrylamide gel. Electrophoretic profiles showed that most of the RILs had a similar profile to the winter tolerant parent Checo (Fig. 2).

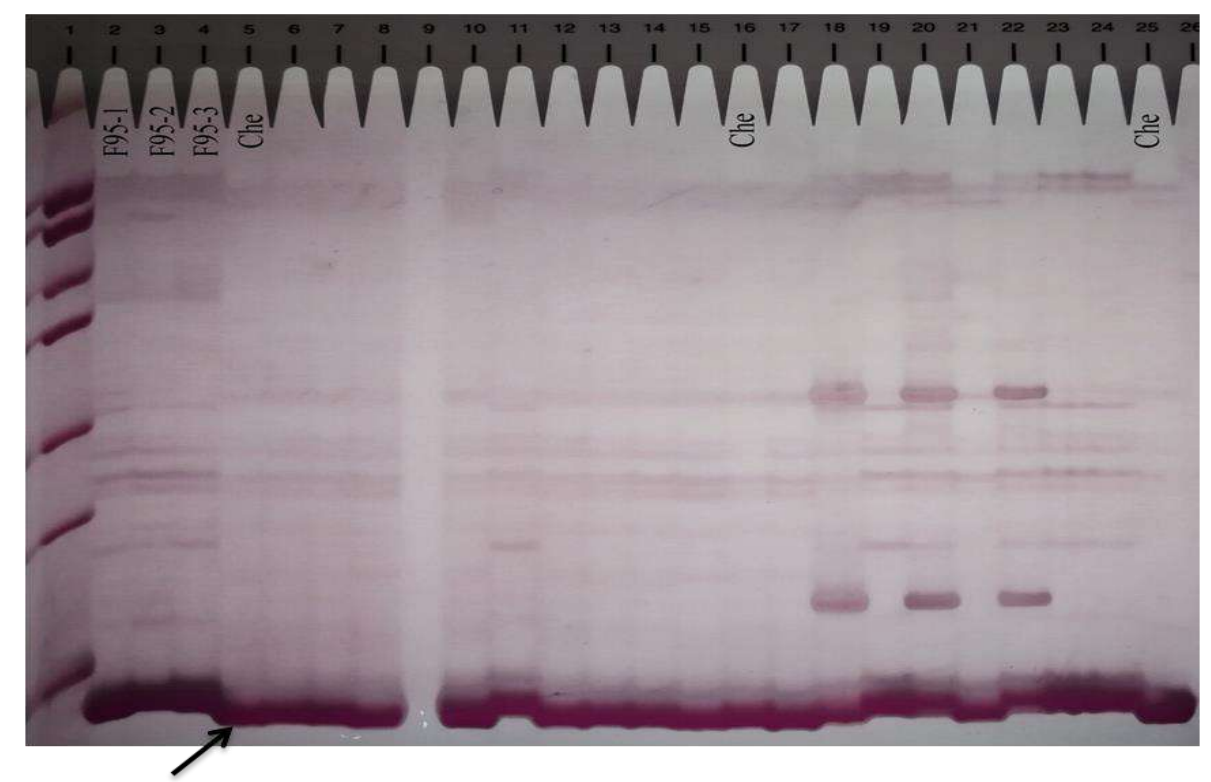

Figure 2. PAGE profile with marker EST 1109. 1: Marker 50 bp DNA Ladder (GeneDireX), 2-4: F95-927; 5: Checo; 6-15: Checo/F95-927 RILs; 16: Checo; 17-24: Checo/F95-927 RILs; 25: Checo. 
The Anova analysis for marker EST1109 showed a distinct significant association with frost tolerance (Table 1).

Studying RILs distribution for plants tolerance to low temperatures correlated with EST1109 marker alleles was observed that for RILs with Checo allele (C) the values for frost tolerance ranged between 1 and 4 (Fig. 3). In case of RILs with F95-927 allele (F), values ranged between 1.5 and 6 . The value of susceptible parent F95-927 was 9, meaning that seedlings did not survived.

Table 1. Anova t-test for marker EST1109

\begin{tabular}{|l|c|c|c|c|}
\hline \multicolumn{5}{|c|}{ Frost tolerance - marker EST1109 } \\
\hline Group & Average & Difference & Haplotype No. & P-value \\
\hline Haplotype C & 2.2 & 1.8 & 24 & \multirow{2}{*}{$0.00046^{* * *}$} \\
\hline Haplotype F & 4 & & 13 & \\
\hline
\end{tabular}

Legend: Haplotype C - RILs with Checo allele; Haplotype F- RILs with F95-927 allele.

$* *-\mathrm{p}<0.001$

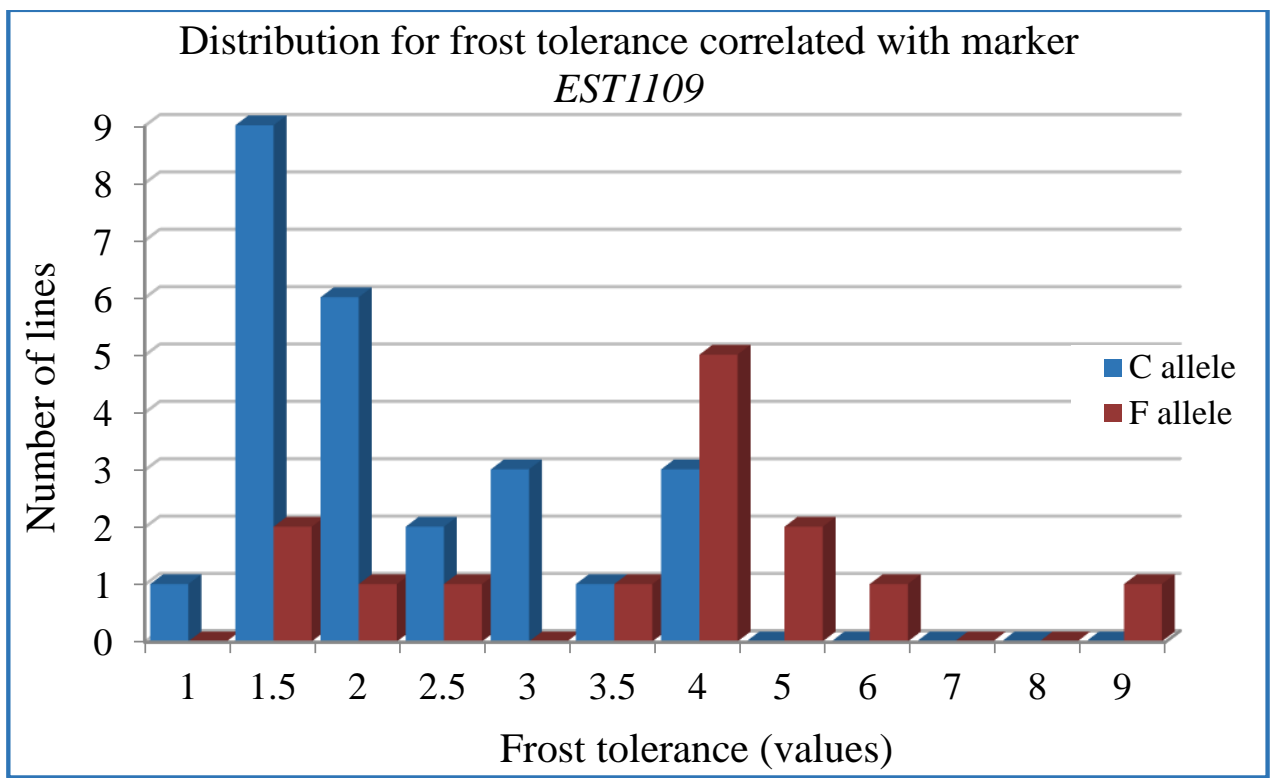

Figure 3. RILs distributions for frost tolerance correlated with EST1109 marker alleles.

Our results suggest the presence of other mechanism based on metabolism of glycoproteins, as response to chilling stress, for frost tolerance in Checo, than those previously reported for marker EST1109 (LIU, 2017).

The polymorphic marker AD59 is also considered to be associated with a QTL for frost tolerance (LEJEUNEHENAUT, 2008). This marker highlighted a clear polymorphism, a PCR product about $420 \mathrm{bp}$ in Checo and of $350 \mathrm{bp}$ in F95-927.

Following the analysis with this SSR marker, results indicate a similarity of profiles between the parent Checo and 21 RILs, between the parent F95-927 and four ones, while 10 RILs were heterozygous forms. Six RILs, from a total of 41 , did not revealed amplification products on agarose gel (Fig. 4).
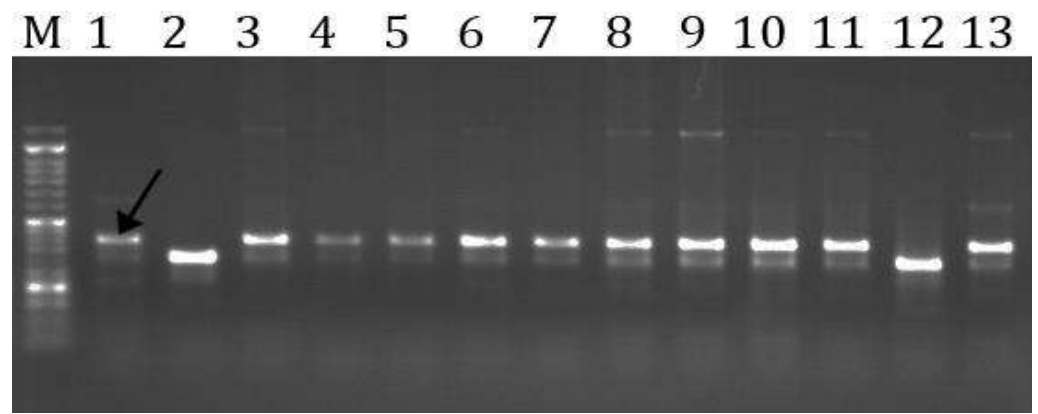

Figure 4. Electrophoretic profiles with marker AD59. M: 50bp GeneDireX, 1: Checo; 2: F95-927; 3-13: Checo/F95-927 RILs. 
The values for RILs distribution for plants tolerance to low temperatures correlated with AD59 marker alleles ranged between 1 and 6 for the carriers of $C$ allele, between 2.5 and 5 for the RILs with $\mathrm{F}$ allele and between 1.5 and 4 for heterozygous forms. Susceptible line
F95-927 was scored with 9 (seedlings did not survived; Fig. 5).

Statistical analysis performed with Anova for marker AD59 showed a significant association with frost tolerance (Table 2).

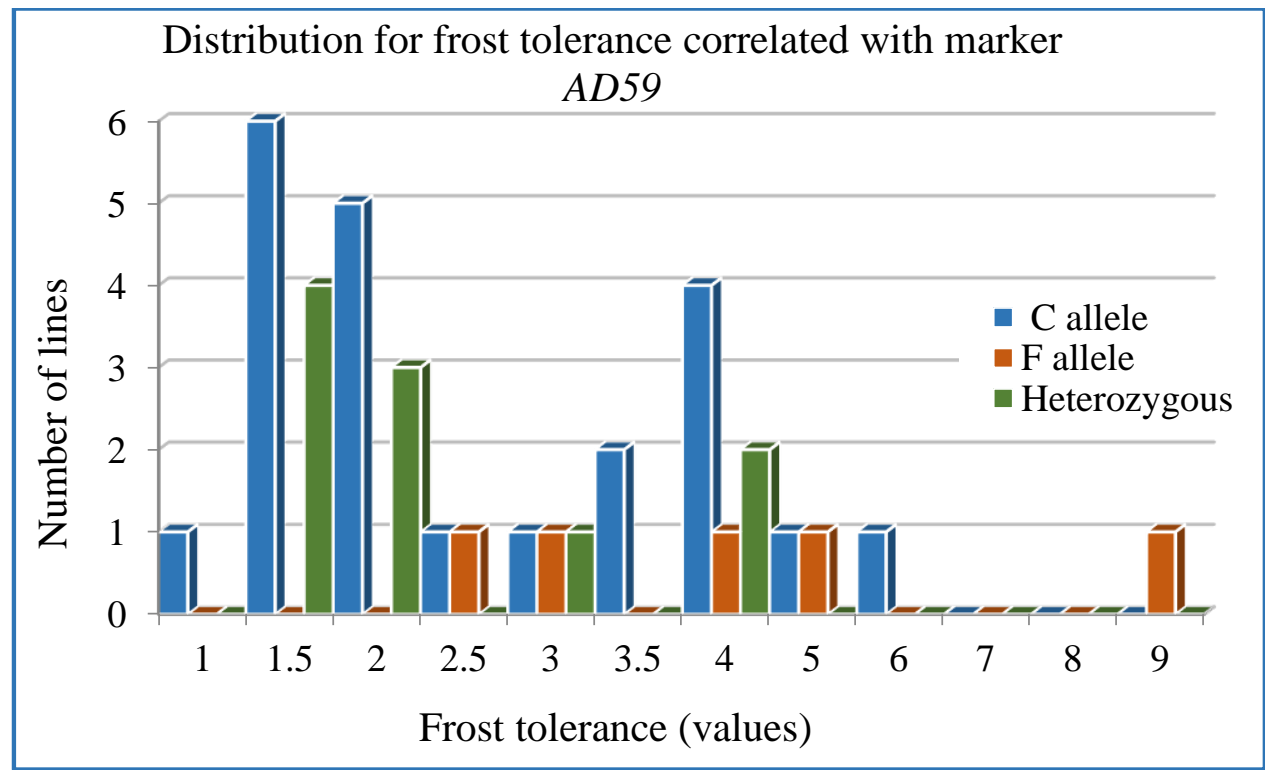

Figure 5. RILs distributions for frost tolerance correlated with AD59 marker alleles.

Table 2. Anova $t$-test for winter frost resistance in association with marker AD59

\begin{tabular}{|l|c|c|c|c|}
\hline \multicolumn{5}{|c|}{ Frost tolerance-marker AD59 } \\
\cline { 1 - 4 } Group & Average & Difference & Haplotype. No. & palue \\
\hline Haplotype C & 2.7 & 2 & 21 & \multirow{2}{*}{$0.0156^{*}$} \\
\hline Haplotype F & 4.7 & - & 4 & \\
\hline Heterozygous forms & 2.3 & 2.4 & 10 & \\
\hline
\end{tabular}

Legend: $*-p<0.05$

PCR analyses with marker $A D 159$ revealed different electrophoretic profiles between the two parents F95-927 (120 bp and $240 \mathrm{bp}$ ) and Checo (140bp and $260 \mathrm{bp}$ ). From a total of 41 lines, 17 had a profile similar with the resilient parent Checo, 14 lines had a profile similar with susceptible parent F95-927 and 10 of them were heterozygous forms (Fig. 6).

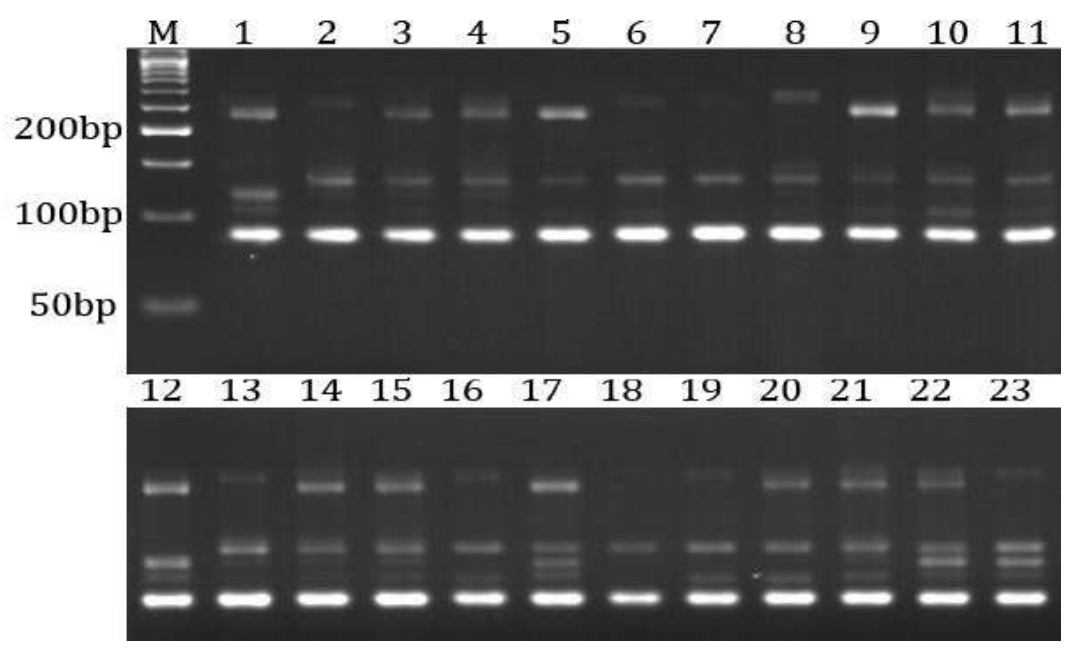

Figure 6. Electrophoretic profiles with marker $A D 159$. M: 50bp GeneDireX; 1: F95-927; 2: Checo; 3-11: Checo/F95-927 RILs; 12: F95-927; 13: Checo; 14-23: Checo/F95-927 RILs. 
Distribution for earliness correlated with marker AD159 revealed values between 120-124 days for RILs with $\mathrm{C}$ allele. For the RILs with $\mathrm{F}$ allele values ranged between 120-124 days, most of them needed 123 days from $1^{\text {st }}$ January to the end of flowering time. Values for heterozygous RILs were between 120-124 days (Fig. 7).

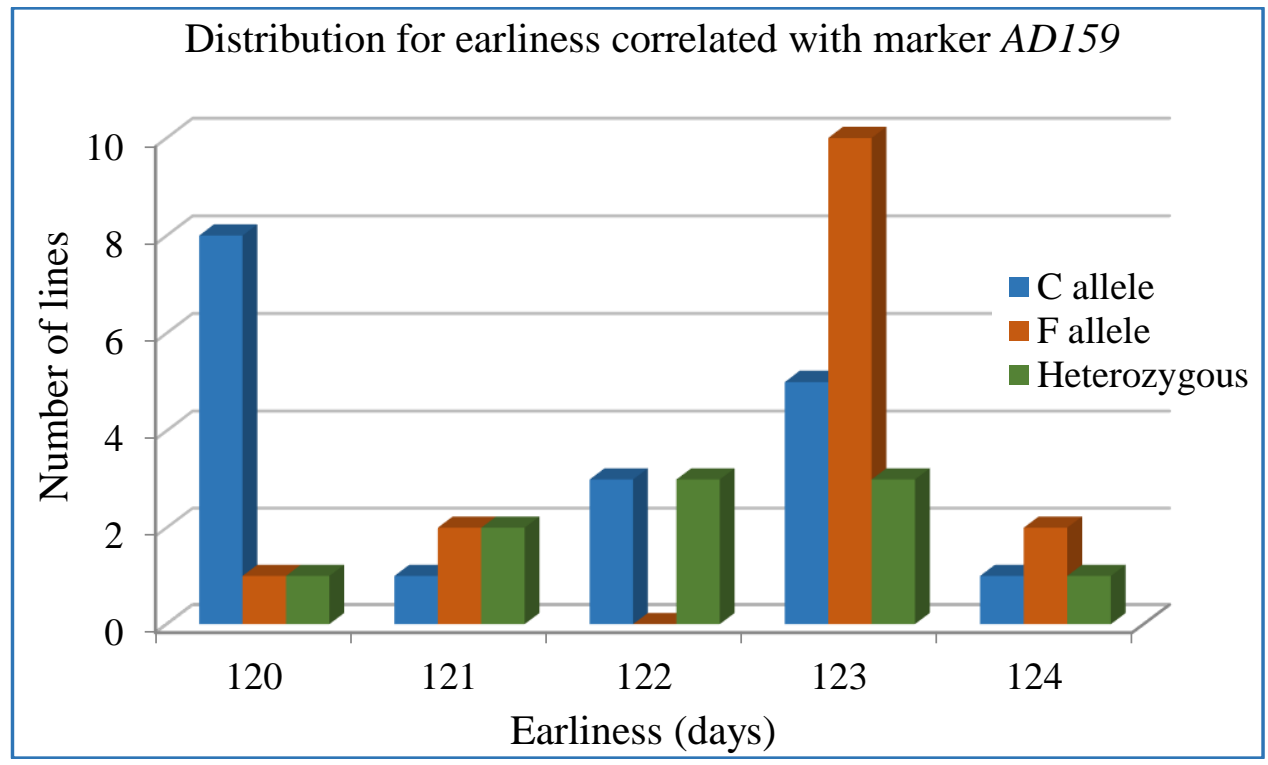

Figure 7. RILs distributions for earliness correlated with marker AD159.

Statistical analysis performed with Anova for marker $A D 159$ showed a significant association with earliness (Table 3). This marker was located on LGVI chromosome group (Dumont, 2009) and it was found to be associated with a QTL for winter frost tolerance (WFD winter frost damage) due to raffinose concentration (RafT2.b) and electrolyte leakage (LeakCleS2).

Table 3. Anova t-test for marker $A D 159$ in association with earliness

\begin{tabular}{|l|c|c|c|c|}
\hline \multicolumn{5}{|c|}{ Earliness - marker AD159 } \\
\hline Group & Average & Difference & Haplot. No. & P-value \\
\hline Haplotype C & 121 & 2 & 17 & \multirow{2}{*}{0.0339} \\
Haplotype F & 123 & - & 14 & \\
\hline Heterozygous forms & 122 & 1 & 10 & \\
\hline
\end{tabular}

Legend: $*-p<0.05$

\section{Conclusions}

This study confirmed that EST1109 is a useful marker for applied markers assisted selection for frost tolerance of field pea.

Results suggest that a possible new element is involved in tolerance to winter hardiness.

The frost tolerant accessions identified in this study may be used as valuable donors for developing new winter pea varieties with enhanced frost tolerance.

\section{Acknowledgements}

This work was funded by the Romanian Ministry of Education and Research and carried out within the projects: PN16-16.01.07 (2016-2017) and P.N. 1925.01.04 (2019-2022).

\section{References}

1. BADARUDDIN M, MEYER DW. Factors modifying frost tolerance of legume species. Crop science. 2001 Nov; 41(6):1911-6. DOI: 10.2135/cropsci2001.1911

2. CONȚESCU E.L. A simple and rapid DNA isolation method from dry pea seeds suitable for PCR analyses. Romanian Agricultural Research. 2018 (35):15-9. www.incda-fundulea.ro Print ISSN 1222-4227; Online ISSN 2067-5720

3. DUMONT E, FONTAINE V, VUYLSTEKER C, SELLIER $\mathrm{H}$ et al. Association of sugar content QTL 
and PQL with physiological traits relevant to frost damage resistance in pea under field and controlled conditions. Theor Appl Genet. 2009 May 1; 118 (8): 1561-71. DOI: 10.1007/s00122-009-1004-7

4. KLEIN A, HOUTIN H, ROND C, MARGET P et al. QTL analysis of frost damage in pea suggests different mechanisms involved in frost tolerance. Theor Appl Genet. 2014 Jun 1; 127(6):1319-30. doi: 10.1007/s00122-014-2299-6

5. LEJEUNE-HÉNAUT I, HANOCQ E, BÉTHENCOURT L, FONTAINE $\mathrm{V}$ et al. The flowering locus Hr colocalizes with a major QTL affecting winter frost tolerance in Pisum sativum L. Theor Appl Genet. 2008 May 1; 116(8):1105-16. DOI: 10.1007/s00122008-0739-x

6. LIU R, FANG L, YANG T, ZHANG X et al. Markertrait association analysis of frost tolerance of 672 worldwide pea (Pisum sativum L.) collections. Scientific reports. 2017 Jul 19; 7(1):1-0. doi: 10.1038/ s41598-017-06222-y
7. MEYER DW, BADARUDDIN M. Frost tolerance of ten seedling legume species at four growth stages. Crop Science. 2001 Nov; 41(6):1838-42. DOI: 10.2135/cropsci2001.1838

8. SIN GH. AND PARTAL E. Influenţa rotaţiei şi a fertilizării asupra producției de grâu și porumb în contextul variațiilor climatice. Anale INCDA Fundulea, 2010, vol. LXXVIII, nr. 1. p. 100-107.

9. STODDARD FL, BALKO C, ERSKINE W, KHAN $\mathrm{HR}$ et al. Screening techniques and sources of resistance to abiotic stresses in cool-season food legumes. Euphytica. 2006 Jan 1; 147(1-2):167-86. DOI: 10.1007/s10681-006-4723-8

10. WELLER JL, LIEW LC, HECHT VF, RAJANDRAN $\mathrm{V}$ et al. A conserved molecular basis for photoperiod adaptation in two temperate legumes. Proceedings of the National Academy of Sciences. 2012 Dec 18; 109(51):21158-63. doi.org/10.1073/pnas.1207943110

11. https://insse.ro/cms/sites/default/files/field/publicatii/prod uctia_vegetala_la_principalele_culturi_in_anul_2019.pdf

12. http://www.fao.org/faostat/en/\#data/QC 